Published in final edited form as:

J Am Chem Soc. 2016 August 17; 138(32): 10276-10283. doi:10.1021/jacs.6b05481.

\title{
Lithium Enolates Derived from Pyroglutaminol: Mechanism and Stereoselectivity of an Azaaldol Addition
}

\author{
Michael J. Houghton $\ddot{Y}$, Christopher J. Huck ${ }^{\ddot{Y}}$, Stephen W. Wright ${ }^{\ddagger}$, and David B. Collum ${ }^{\ddot{Y}},{ }^{*}$ \\ ŸDepartment of Chemistry and Chemical Biology Baker Laboratory, Cornell University Ithaca, \\ New York 14853-1301 \\ ¥Worldwide Medicinal Chemistry, Pfizer Global Research and Development, 445 Eastern Point \\ Road, Groton, CT 06340
}

\begin{abstract}
A lithium enolate derived from an acetonide-protected pyroglutaminol undergoes a highly selective azaaldol addition with (E)-N-phenyl-1-[2-(trifluoromethyl)phenyl]methanimine. The selectivity is sensitive to THF concentration, temperature, and the presence of excess lithium diisopropylamide base. Rate studies show that the observable tetrasolvated dimeric enolate undergoes reversible deaggregation, with the reaction proceeding via a disolvated-monomer-based transition structure. Limited stereochemical erosion stems from the intervention of a trisolvatedmonomer-based pathway, which is suppressed at low THF concentrations and elevated temperature. Endofacial selectivity observed with excess lithium diisopropylamide (LDA) is traced to an intermediate dianion formed by subsequent lithiation of the monomeric azaaldol adduct, which is characterized as both a dilithio form and a trilithio dianion-LDA mixed aggregate.
\end{abstract}

\section{Introduction}

A program at Pfizer to develop anti-inflammatory agents has focused on the functionalizations of protected pyroglutaminol (eq 1). ${ }^{1}$ The readily available hemiaminals of pyroglutaminol have been subjects of intense scrutiny and can be functionalized exofacially with moderate selectivity sufficient for many applications. ${ }^{2}$ Acetonide-protected derivative 1a shows more promise than the more popular benzylidene analog $\mathbf{1 b} .^{3}$ Rarely reported functionalization from the concave face relies largely on epimerization and is poorly selective. $^{4}$

\footnotetext{
*David B. Collum,dbc6@cornell.edu.

Supporting Information: Spectroscopic, kinetic, and computational data and authors for reference 12. This material is available free of charge via the internet at http://pubs.acs.org.

Notes

The authors declare no competing financial interests.
} 


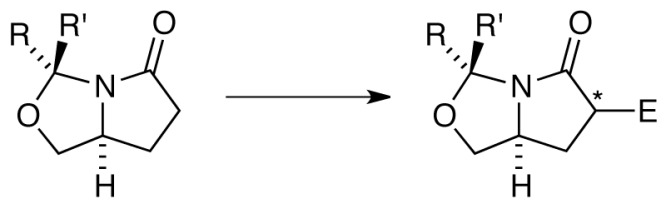

1a; $R, R^{\prime}=M e$

1b; $R=P h ; R^{\prime}=H$

The Collum group became interested in lithium enolates in hopes of correlating their structure and solvation with the stereochemistry of their functionalizations. ${ }^{5}$ We have previously described structural studies of a dozen enolates within the class, ${ }^{3}$ all of which form mixtures of tetrasolvated tetramers and tetrasolvated dimers as exemplified by acetonide-derived enolates (Chart 1). These enolates are deceptively hindered, causing observable atropisomerism and slow solvent exchanges within the tetramer form.

We describe herein investigations of an azaaldol addition (Scheme 1) ${ }^{6,7}$ Reactions of imines offer excellent templates for the study of organolithium structure-reactivity relationships, especially in conjunction with variations of hemiaminal protecting group on the enolate. ${ }^{8}$ We are following on the heels of Moloney and coworkers, ${ }^{9}$ who reported an azaaldol addition to tosylimines with a protected pyroglutaminol-derived enolate that proceeds with high exo selectivity but less control at the $\beta$-amino position. The optimized selectivity in our case is exceptional at both positions. We trace the stereocontrol to a dominant monomerbased pathway. Erosion of selectivity originates in a mechanistically distinct, more highly solvated form. We also show that the inherent exo selectivity can be changed to endo with excess lithium diisopropylamide (LDA) owing to the intervention of an N,O-dianion generated from the 1,2-adduct akin to that proposed by the Moloney group. ${ }^{9}$

\section{Results}

Lithium enolate $\mathbf{3}$ was previously characterized as tetrasolvated tetramer $\mathbf{3 a}$ and tetrasolvated dimer $\mathbf{3 b}$. Dimer $\mathbf{3 b}$ is the only observable form in 3.0-12.3 M tetrahydrofuran (THF). Similarly, mixed aggregate 5 was previously characterized with ${ }^{6} \mathrm{Li}$ and ${ }^{15} \mathrm{~N}$ NMR spectroscopies ${ }^{10}$ using $\left[{ }^{6} \mathrm{Li},{ }^{15} \mathrm{~N}\right] \mathrm{LDA}^{11}$ and augmented by computational studies. ${ }^{3}$ The same methods were used to characterize an intermediate dianion (vide infra). Structural and mechanistic studies were supported by density functional theory (DFT) calculations at the B3LYP/6-31G(d) level with single-point calculations at the MP2 level of theory. ${ }^{12,13}$ Only the calculations needed to make specific points are included herein; the preponderance of the computational results obtained to explore structure and reactivity are archived in the supporting information.

\section{Azaaldol addition: stereoselectivity}

The azaaldol addition in Scheme 1 was used to probe structure-reactivity relationships. The $\mathrm{CF}_{3}$ moiety allowed us to exploit ${ }^{19} \mathrm{~F}$ NMR spectroscopy ${ }^{14}$ to monitor diastereoselectivities and reaction rates. Major isomer 4 and two minor isomers (6 and 7) from the azaaldol 
addition of enolate 3 were assigned by using COSY, HSQC, HMBC, and ROESY spectroscopies. The same methods provided more compelling assignments when the purified $\beta$-aminolactams were $\mathrm{N}$-lithiated and $\mathbf{8}$ and $\mathbf{1 0}$, which exist as conformationally constrained chelated monomers (vide infra), were characterized (Scheme 2).

A quick survey of a range of hemiaminal-protected pyroglutaminols whose enolates were characterized previously ${ }^{3}$ showed mediocre selectivities for reaction with $\mathbf{2}$, as evidenced by multiple resonances in the ${ }^{19} \mathrm{~F}$ NMR spectra of the crude products. By contrast, mixing enolate 3 with imine $2^{15}$ in neat THF at $-78^{\circ} \mathrm{C}$ showed promising results, affording $\beta$ amino esters $\mathbf{4}$ and $\mathbf{6}$ in 10:1 selectivity to the exclusion of other isomers $(<0.5 \%)$. A number of parameters were examined to optimize the selectivity.

Mixing imine $\mathbf{2}$ and enolate $\mathbf{3}$ in neat THF solution yielded no changes in selectivity with percent conversion (0.10-1.0 equiv of imine 2 ) whether monitored in situ with ${ }^{19} \mathrm{~F}$ NMR spectroscopy or quenching, and this result showed that mixed-aggregate-derived feedback loops (autocatalysis or autoinhibition) are inconsequential. ${ }^{16,17}$ Maintaining the resulting lithiated adducts at elevated temperature $\left(-40^{\circ} \mathrm{C}\right)$ for $2.0 \mathrm{~h}$ before quenching resulted in no erosion of selectivity, which indicated that stereochemical scrambling owing to retro azaaldol addition was also not occurring.

THF concentration and temperature proved to be the key parameters (Table 1). Raising the temperature increased the selectivity — an unusual inverted dependence. Decreasing the THF concentration also increased the selectivity (see Table 1), which displayed a linear relationship versus THF concentration in toluene cosolvent (Figure 1). (Depiction of the reciprocal relationship-the minor-major ratio-in Figure 1 appears in the context of the rate studies described below.) Because conventional wisdom suggests that both higher temperatures and lower THF concentrations promote tetrameric enolates over dimeric enolates, ${ }^{18}$ it might be tempting to infer the intervention of a tetramer-based mechanism, but that would be a mistake. The two dependencies are consistent with the stereochemical erosion deriving from a pathway that demands elevated solvation numbers. We see no dependence whatsoever of stereoselectivity on enolate concentration, which indicates that the major and minor products arise from a common aggregation state.

\section{Azaaldol addition: structure of the lithiated product}

To state the obvious, isolated product $\mathbf{4}$ is not the same as the initially formed lithium salt depicted generically as $\mathbf{8}$. Monitoring the azaaldol addition of enolate $\mathbf{3}$ to imine $\mathbf{2}$ with ${ }^{19} \mathrm{~F}$ NMR spectroscopy showed $\mathbf{8}$ and traces of $\mathbf{9}$. Metalation of the purified, fully characterized $\beta$-amino lactams 4 and $\mathbf{6}$ with 1.0 equiv of LDA regenerated $\mathbf{8}$ and $\mathbf{9}$, respectively, as expected (Scheme 2). Using $\left[{ }^{15} \mathrm{~N}\right] \mathbf{4}$ prepared from $\left[{ }^{15} \mathrm{~N}\right]$ aniline, we observed a ${ }^{6} \mathrm{Li}$ doublet and ${ }^{15} \mathrm{~N}$ triplet $\left(J_{\mathrm{Li}-\mathrm{N}}=6.2 \mathrm{~Hz}\right)$ consistent with the monomer substructure of $8 .{ }^{10}$ Mixtures of lithium amides $\mathbf{8}$ and $\mathbf{1 0}$ show no heteroaggregation, further supporting the monomer assignment. Chelation by the carbonyl and solvation by two THF ligands, yielding $\mathbf{8 a}$, is supported by DFT calculations: a non-chelated trisolvate was computed to be $10 \mathrm{kcal} / \mathrm{mol}$ less stable and a trisolvated chelate, although seemingly plausible based on compelling evidence of high-coordinate lithium, ${ }^{19}$ was not computationally viable. We suspected that 
the aryl moiety precluded higher coordination, yet calculation with an NH rather than an $\mathrm{NPh}$ moiety failed to afford a minimum corresponding to a chelated trisolvate.

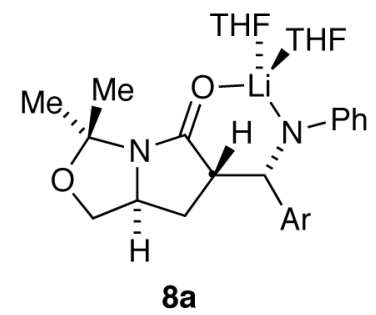

\section{Azaaldol addition: kinetics and mechanism ${ }^{17}$}

An equimolar mixture of enolate $\mathbf{3}$ and imine $\mathbf{2}$ under conditions in which dimer $\mathbf{3 b}$ was the only observable form showed an exponential decay manifesting none of the aberrant curvatures (sigmoids or stalling) that would be expected if autocatalysis or autoinhibition were intervening. Addition at normal enolate concentration $(0.10 \mathrm{M})$ in neat THF and pseudo-first-order in imine $(0.005 \mathrm{M})$ followed a clean first-order decay from which pseudofirst-order rate constants $\left(k_{\text {obsd }}\right)$ were extracted. $k_{\text {obsd }}$ was independent of the initial concentration of imine $\mathbf{2}$, which was also consistent with a first-order dependence on $\mathbf{2}$.

A plot of $k_{\text {obsd }}$ versus THF concentration using toluene as cosolvent showed a zeroth-order dependence (Figure 2). A plot of $k_{\text {obsd }}$ versus enolate concentration showed a half-order dependence (Figure 3) consistent with a dimer-monomer pre-equilibrium. The idealized rate $\operatorname{law}^{20}$ (eq 2) was consistent with the mechanism shown generically in eqs $3-5$. Inclusion of the THF-dependent term in the rate law and the trisolvated-monomer-based pathway in eq 5 (see 12a and 12b below) stems from the stereochemical independence of enolate concentration and first-order dependence on THF concentration (see Figure 1). ${ }^{21}$ This contribution is far too small to detect in the absolute rates, but it is readily discerned in the relative rates.

$$
\begin{aligned}
& \mathrm{d}[\text { enolate }] / \mathrm{d} t=k[\text { imine }]^{1}[\text { enolate }]^{1 / 2}\left\{1+k^{\prime}[\mathrm{THF}]^{1}\right\} \\
& \left.1 / 2(\text { enolate })_{2} \underset{\mathbf{3 b}}{(\mathrm{THF}}\right)_{2}+\mathrm{THF} \stackrel{K_{\mathrm{eq}}}{\rightleftharpoons}(\text { enolate })(\mathrm{THF})_{2}
\end{aligned}
$$

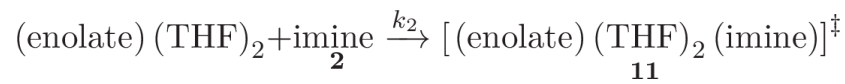

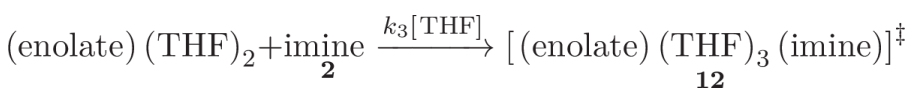


With clear stoichiometric guidance from the kinetics, we examined the origins of the stereochemistry by using DFT calculations. These calculations supported the experimentally observed disolvation of the transition structure and were consistent with the observed preference for transition structure 11a (progenitor of major product 4) over transition structure $11 \mathrm{~b}$ that leads to minor isomer $\mathbf{6}$. Inspection of the three-dimensional structures (with the aid of a computer graphics interface) left us unsure of the origins of this preference. Analogous transition structures that led to endo adducts were $22.5 \mathrm{kcal} / \mathrm{mol}$ less stable. Stereochemical erosion was shown experimentally to stem from low contributions from trisolvated-monomer-based addition. Computational studies concur by showing that trisolvated transition structures 12a and 12b were less stable than the disolvates and displayed the opposite selectivity (Scheme 3).

\section{Azaaldol addition: endo selectivity with excess LDA}

A dominant endo addition appears when excess LDA is present (eq 6). Organolithium chemists may be tempted to invoke addition via previously characterized LDA-enolate mixed dimer 5. ${ }^{3}$ Once again, this would be wrong. An analogous endo selectivity was detected by Moloney and coworkers ${ }^{9}$ and suggested to arise from an intervening dianion. The key observation that supported their thesis is that control at the $\beta$-amino position of the endo adducts is identical to that in the exo adducts. Indeed, we subsequently traced the selectivity to an N,O-dianion as described below.

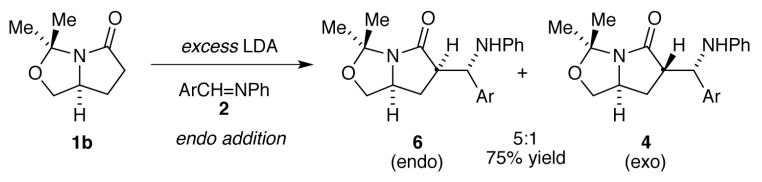

\section{Endo selectivity: an N,O-dianion}

Carrying out the azaaldol addition by using excess LDA and monitoring it with ${ }^{19} \mathrm{~F}$ NMR spectroscopy revealed the initial formation of adduct $\mathbf{8}$, which was subsequently converted to two new species at $-78{ }^{\circ} \mathrm{C}$ depending on the amount of LDA added (Figure 4). These same species could be generated from purified adduct $\mathbf{4}$ or $\mathbf{7}$ by adding LDA, with 2.0 equiv producing a new species displaying one ${ }^{19} \mathrm{~F}$ resonance believed to be the dianion depicted generically as $\mathbf{1 3}$ (eq 7). ${ }^{15} \mathrm{~N}$-labelled $\mathbf{1 3}$ manifested a sharp ${ }^{6} \mathrm{Li}$ doublet (Figure $4 \mathrm{~A}$ ) and a broad, unresolved ${ }^{15} \mathrm{~N}$ multiplet that collapsed to a singlet on single-frequency ${ }^{6} \mathrm{Li}$ decoupling. The spectra are consistent with a doubly bridging dianion. DFT calculations showed the most stable form and highest solvation state to be trisolvate 13a, which displayed provocative evidence of an Li-F contact (2.03 $\mathrm{A}){ }^{22}$ Dianion 13b showed no such $\mathrm{Li}-\mathrm{F}$ interaction, however, and was $3.6 \mathrm{kcal} / \mathrm{mol}$ less stable than 13a. In theory, 13 should have shown two distinct ${ }^{6} \mathrm{Li}$ resonances, but we are untroubled that they fail to resolve or exchange rapidly. 


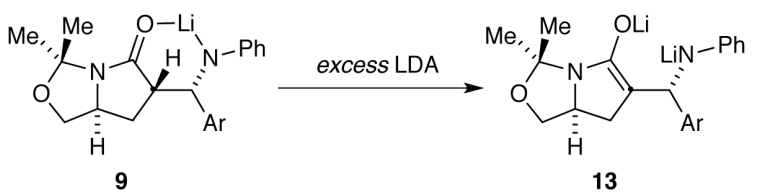

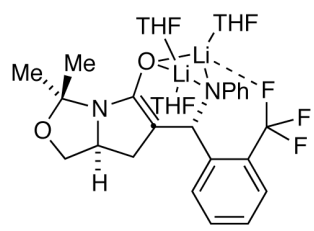

$13 a$

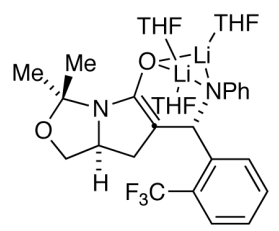

$13 b$

Forming dianion 13 in the presence of excess LDA afforded a new species shown to be a trilithiated mixed aggregate of gross structure 14 with ${ }^{6} \mathrm{Li}$ and ${ }^{15} \mathrm{~N}$ NMR spectroscopies aided by ${ }^{6} \mathrm{Li}$ and ${ }^{15} \mathrm{~N}$ single-frequency decoupling. $\left[{ }^{6} \mathrm{Li},{ }^{15} \mathrm{~N}\right] \mathrm{LDA}$ showed that two of the three ${ }^{6} \mathrm{Li}$ resonances were coupled to LDA (Figure $4 \mathrm{a}$ ). The corresponding ${ }^{15} \mathrm{~N}$ spectrum displayed a broad quintet consistent with coupling to two slightly magnetically inequivalent ${ }^{6} \mathrm{Li}$ nuclei. ${ }^{6} \mathrm{Li}$ and ${ }^{15} \mathrm{~N}$ spectra recorded on a sample prepared from $\left[{ }^{15} \mathrm{~N}\right] 5$ showed coupling of the anilide ${ }^{15} \mathrm{~N}$ to two resonances (see Figure $4 \mathrm{~b}$ ) and a broad quintet in the ${ }^{15} \mathrm{~N}$ spectrum. The connectivity of $\mathbf{1 4}$ derives from coupling data. Computational studies of $\mathbf{1 4}$ uniformly showed a transannular $\mathrm{Li}-\mathrm{O}$ contact in a ladder motif with three coordinated THF ligands. Evidence of a $\mathrm{Li}-\mathrm{F}$ contact in 14a is provocative but not net stabilizing.

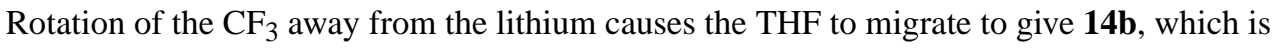
also more stable by $2.4 \mathrm{kcal} / \mathrm{mol}$. We have never witnessed (or at least noticed) such a THF migration in a simple ground-state minimization. ${ }^{23}$
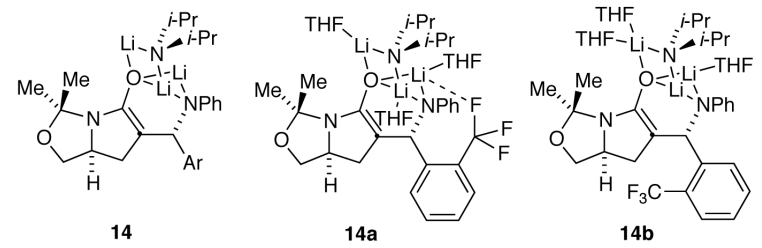

Clearly, endo isomer $\mathbf{7}$ is derived when dianion $\mathbf{1 3}$ or $\mathbf{1 4}$ is protonated from the exo face, leaving the stereogenic center at the $\beta$ carbon intact. We explored half a dozen alternative quenching protocols—by no means an exhaustive study—but found no improvements over the simple aqueous quench.

\section{Dehydroamination}

We conclude the results section with some minor housekeeping. Warming lithiated azaaldol product 8 to temperatures above $-30{ }^{\circ} \mathrm{C}$ afforded complex products that appeared by mass spectrometry to be Claisen condensation products of little interest to us. We also, however, noted facile dehydroamination even at low temperatures when low THF concentrations were used (eq 8). These reactions afforded alkylidene $\mathbf{1 5}$ exclusively as the less stable $E$ isomer 
(shown by NOESY studies). The $E$ isomer equilibrated to the $Z$ isomer, 16, on standing at $25^{\circ} \mathrm{C}$ for $0.5 \mathrm{~h}$. All such byproducts were excluded by keeping the temperature low and the THF concentrations at $\geq 1.0 \mathrm{M}$. It is not obvious why the elimination follows this pattern.

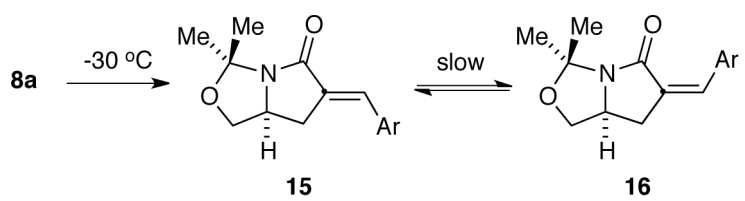

\section{Discussion}

For the second paper in a two-part series, we investigated the reactivity of protected pyroglutaminol-derived lithium enolates $(\mathbf{3})$ to better understand the origins of their reactivity and selectivity. Our collaborators in the Pfizer group are motivated by medicinal chemistry interests: the bicyclo[3.3.0] ring system is a potential source of stereocontrol needed for a program to develop anti-inflammatory agents. ${ }^{1}$ The interest of the Collum group was piqued by the flexibility offered by the hemiaminal linkage that might be used to modify enolate structure, reactivity, and reaction mechanism. Our interest in imine chemistry in general ${ }^{8}$ and the azaaldol addition in particular ${ }^{7}$ stems from the versatility of the two imine appendages in modulations of structure-reactivity relationships.

The results are summarized in Scheme 4. Enolate 3 was previously shown to exist as tetrasolvated dimer $\mathbf{3 b}$ over a broad range of THF concentrations. The reluctance to form tetramers except under extremely low THF concentrations was attributed to deceptively high steric congestion within the cubic tetramers. Enolate $\mathbf{3}$ undergoes addition to imine $\mathbf{2}$ with $>100: 1$ stereocontrol via disolvated-monomer-based transition structure $\mathbf{1 1}$ to give essentially a single isomeric adduct, $\mathbf{4}$, in $70-80 \%$ yield under optimal conditions (1.0 M THF-toluene and $-55^{\circ} \mathrm{C}$ ). DFT calculations mimicked the diastereoselectivity (Scheme 3); however, the selectivity dropped at lower temperatures and higher THF concentrations (see Table 1). These unusual dependencies—especially the inverted temperature dependencewere traced to a minor trisolvated-monomer-based pathway and open transition structure $\mathbf{1 2}$. Calculations mimicked experiment by showing that the preference for $\mathbf{1 2 b}$ over 12a (Scheme 3) reversed selectivity. This result is a relatively rare example of the stereocontrol of an organolithium reaction being traced to specific mechanistic events. ${ }^{24}$ The THF concentration dependence reinforces the assertion ${ }^{17}$ that optimizations should include changes in solvent concentrations, not just solvent.

In a related azaaldol addition of a pyroglutaminol hemiaminal using a toluenesulfonylsubstituted imine, Moloney and coworkers ${ }^{9}$ observed that excess LDA inverts the stereochemistry to predominantly endo and proposed an intermediate dianion. ${ }^{25,26} \mathrm{We}$ observed an analogous 5:1 preference for endo isomer 10 with excess LDA. Despite an affinity for models involving mixed-aggregation-dependent selectivities, Moloney's thesis proved correct: adduct $\mathbf{8} \mathbf{a}$ undergoes further metalation to give a dianion generically drawn 
as 13, which then undergoes exofacial protonation. The 5:1 selectivity was not markedly improved by variations in the quenching agent. Dianion 13 was characterized with $\left[{ }^{6} \mathrm{Li},{ }^{15} \mathrm{~N}\right] \mathrm{LDA}$ and $\left[{ }^{15} \mathrm{~N}\right] \mathbf{2}$ and DFT calculations as trisolvate $\mathbf{1 3 a}$ or $\mathbf{1 3 b}$ as well as LDAdianion mixed aggregate 14a or $\mathbf{1 4 b}$ (see above).

We wondered whether the superior selectivities observed using acetonide-protected enolate $\mathbf{3}$ could be exploited to improve the decidedly inferior results obtained with the more commonly used benzylidene-substituted lactam 1b (eq 9). Could we stem stereochemical leakage? Although the selectivities are not as high, the greater selectivity at low THF concentration and elevated temperature is notable. The poor yield stems from competitive decomposition during protracted reaction times.

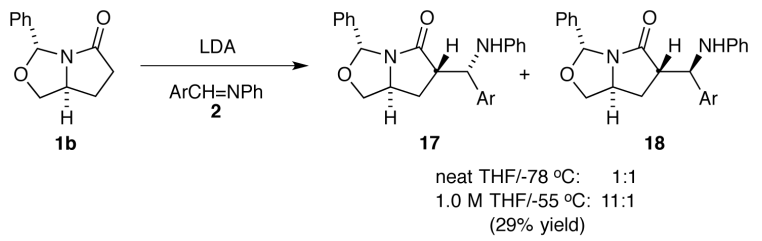

\section{Conclusion}

Several high-water marks in this study are noteworthy. The pyroglutaminol-derived enolates showed their potential as synthons for highly stereoselective functionalization and templates for the study of organolithium structure-reactivity-selectivity relationships. Given the condition-dependent selectivity, we wonder whether additional stereocontrol might be available to previously described functionalizations through judicious choice of reaction conditions. Tracing stereochemical changes to explicit mechanistic changes is also of importance to mechanistic organolithium chemists. Moreover, the characterization of another dianion is noteworthy - these are complex species even by organolithium chemistry standards. $^{27}$

\section{Experimental}

\section{Reagents and solvents}

THF and toluene were distilled from solutions containing sodium benzophenone ketyl. The toluene stills contained approximately $1 \%$ tetraglyme to dissolve the ketyl. LDA, [ $\left.{ }^{6} \mathrm{Li}\right] \mathrm{LDA}$, and $\left[{ }^{6} \mathrm{Li},{ }^{15} \mathrm{~N}\right] \mathrm{LDA}$ were prepared as described previously. ${ }^{11} \mathrm{LDA}$ was titrated for active base by following a literature method. ${ }^{28}$ Air- and moisture-sensitive materials were manipulated under argon with standard glovebox, vacuum line, and syringe techniques. Pyroglutaminol derivatives $\mathbf{1 a}$ and $\mathbf{1 b}$ were prepared by using literature methods. ${ }^{29}$

\section{NMR spectroscopy}

Individual stock solutions of substrates and LDA were prepared at room temperature, mixed in NMR tubes at $-78{ }^{\circ} \mathrm{C}$, and flame-sealed under partial vacuum. Standard ${ }^{6} \mathrm{Li},{ }^{13} \mathrm{C},{ }^{15} \mathrm{~N}$, 
and ${ }^{19} \mathrm{~F}$ NMR spectra were recorded on a $500 \mathrm{MHz}$ spectrometer at 73.57, 125.79, 50.66, and $470.35 \mathrm{MHz}$, respectively. The ${ }^{6} \mathrm{Li},{ }^{13} \mathrm{C},{ }^{15} \mathrm{~N}$, and ${ }^{19} \mathrm{~F}$ resonances were referenced to $0.30 \mathrm{M}\left[{ }^{6} \mathrm{Li}\right] \mathrm{LiCl} / \mathrm{MeOH}$ at $-80{ }^{\circ} \mathrm{C}(0.0 \mathrm{ppm})$, the $\mathrm{CH}_{2} \mathrm{O}$ resonance of THF at $-90{ }^{\circ} \mathrm{C}(67.57$ ppm), neat $\mathrm{Me}_{2} \mathrm{NEt}$ at $-90{ }^{\circ} \mathrm{C}(25.7 \mathrm{ppm})$, and $\mathrm{C}_{6} \mathrm{H}_{5} \mathrm{~F}$ in neat THF at $-80{ }^{\circ} \mathrm{C}(-112.0 \mathrm{ppm})$.

(6S,7aS)-3,3-dimethyl-6-((S)-(phenylamino)(2-(trifluoromethyl)phenyl)methyl)tetrahydro-3H, $5 H$-pyrrolo[1,2-c]oxazol-5-one (4)

Lithium diisopropylamide $(35.9 \mathrm{mg}, 0.34 \mathrm{mmol})$ was dissolved in toluene $(1.079 \mathrm{~mL})$ and THF $(0.26 \mathrm{~mL})$ and cooled to $-55^{\circ} \mathrm{C}$. To this mixture was added $1 \mathbf{a}(50 \mathrm{mg}, 0.32 \mathrm{mmol})$ dissolved in toluene $(1.34 \mathrm{~mL})$ and was allowed to stir for 10 minutes. Imine $2(104.4 \mathrm{mg}$, $0.42 \mathrm{mmol})$ dissolved in toluene $(1.34 \mathrm{~mL})$ was added. After $2 \mathrm{~h}$, the reaction was quenched with $\mathrm{pH} 7$ phosphate buffer $(6 \mathrm{~mL})$ and allowed to warm. The mixture was extracted $3 \times 20$ $\mathrm{mL}$ with $\mathrm{Et}_{2} \mathrm{O}$, dried over $\mathrm{Na}_{2} \mathrm{SO}_{4}$, and rotary evaporated. The resulting yellow oil was purified using flash chromatography using a gradient of ethyl acetate/hexane mixtures and rotary evaporated to yield $102 \mathrm{mg}(78 \%)$ of white solid. $\left(R_{\mathrm{f}}=0.19\right.$ in $40 \%$ EtOAc/hexanes); $\mathrm{mp}=106.9-112.4 ;{ }^{1} \mathrm{H} \mathrm{NMR}\left(400 \mathrm{MHz}, \mathrm{CDCl}_{3}\right) \delta 7.77(\mathrm{~d}, J=8.0 \mathrm{~Hz}, 1 \mathrm{H}), 7.68(\mathrm{~d}, J=7.9$ $\mathrm{Hz}, 1 \mathrm{H}), 7.52(\mathrm{t}, J=7.6 \mathrm{~Hz}, 1 \mathrm{H}), 7.36(\mathrm{t}, J=7.7 \mathrm{~Hz}, 1 \mathrm{H}), 7.05(\mathrm{t}, J=7.8 \mathrm{~Hz}, 2 \mathrm{H}), 6.66(\mathrm{t}, J$ $=7.3 \mathrm{~Hz}, 1 \mathrm{H}), 6.53(\mathrm{~d}, J=8.0 \mathrm{~Hz}, 2 \mathrm{H}), 5.30(\mathrm{~s}, 1 \mathrm{H}), 5.01(\mathrm{~d}, J=7.9 \mathrm{~Hz}, 1 \mathrm{H}), 4.40-4.23$ (m, $1 \mathrm{H}), 4.06$ (dd, $J=8.3,5.7 \mathrm{~Hz}, 1 \mathrm{H}), 3.36$ (appt, $J=8.8 \mathrm{~Hz}, 1 \mathrm{H}$ ), 3.00 (ddd, $J=9.8,7.5$, $2.3 \mathrm{~Hz}, 1 \mathrm{H}), 2.01-1.79(\mathrm{~m}, 2 \mathrm{H}), 1.67(\mathrm{~s}, 3 \mathrm{H}), 1.50(\mathrm{~s}, 3 \mathrm{H}) .{ }^{13} \mathrm{C} \mathrm{NMR}\left(126 \mathrm{MHz}, \mathrm{CDCl}_{3}\right) \delta$ $169.7,145.0,138.5,131.2,128.19\left(\mathrm{q},{ }^{3} J_{\mathrm{C}-\mathrm{F}}=7.8 \mathrm{~Hz}\right), 128.15,127.6,127.3\left(\mathrm{q},{ }^{2} J_{\mathrm{C}-\mathrm{F}}=29.7\right.$ $\mathrm{Hz}), 127.0,125.4\left(\mathrm{q},{ }^{3} J_{\mathrm{C}-\mathrm{F}}=5.9 \mathrm{~Hz}\right), 123.7\left(\mathrm{q},{ }^{1} J_{\mathrm{C}-\mathrm{F}}=275 \mathrm{~Hz}\right), 117.0,112.8,90.4,69.0$, 58.8, 52.9, 52.7, 25.2, 22.6; ${ }^{19} \mathrm{~F} \mathrm{NMR}\left(376 \mathrm{MHz}, \mathrm{CDCl}_{3}\right) \delta-55.5$. HRMS (DART ionization, orbitrap mass analyzer) calcd for $\mathrm{C}_{12} \mathrm{H}_{12} \mathrm{FNO}_{2}[\mathrm{M}+\mathrm{H}] 405.17899$, found 405.17844 .

\section{(6S,7aS)-3,3-dimethyl-6-((R)-(phenylamino)(2-(trifluoromethyl)phenyl)methyl)tetrahydro-3H, $5 H$-pyrrolo[1,2-c]oxazol-5-one (6)}

Lithium diisopropylamide (376 mg, $3.54 \mathrm{mmol}$ ) was dissolved in THF (12 mL) and cooled to $-78{ }^{\circ} \mathrm{C}$. To this mixture was added $\mathbf{1 a}(500 \mathrm{mg}, 3.22 \mathrm{mmol})$ dissolved in THF $(10.3 \mathrm{~mL})$ and was allowed to stir for 10 minutes. Imine $2(104.4 \mathrm{mg}, 0.42 \mathrm{mmol})$ dissolved in THF $(10.3 \mathrm{~mL})$ was added. After $2 \mathrm{~h}$, the reaction was quenched with $\mathrm{pH} 7$ phosphate buffer $(25 \mathrm{~mL})$ and allowed to warm. The mixture was extracted $3 \times 60 \mathrm{~mL}$ with $\mathrm{Et}_{2} \mathrm{O}$, dried over $\mathrm{Na}_{2} \mathrm{SO}_{4}$, and rotary evaporated. The resulting yellow oil was purified using flash chromatography using a gradient of ethyl acetate/hexane mixtures and rotary evaporated to yield $91 \mathrm{mg}$ (7 \%) of white foam. ( $R_{\mathrm{f}}=0.22$ in $40 \%$ EtOAc/hexanes); ${ }^{1} \mathrm{H} \mathrm{NMR}(400 \mathrm{MHz}$, Chloroform- $d$ ) $\delta 7.77(\mathrm{~d}, J=8.0 \mathrm{~Hz}, 1 \mathrm{H}), 7.68(\mathrm{~d}, J=7.9 \mathrm{~Hz}, 1 \mathrm{H}), 7.52(\mathrm{dd}, J=8.3,7.0 \mathrm{~Hz}$, $1 \mathrm{H}), 7.36(\mathrm{t}, J=7.7 \mathrm{~Hz}, 1 \mathrm{H}), 7.05(\mathrm{dd}, J=8.6,7.3 \mathrm{~Hz}, 2 \mathrm{H}), 6.66(\mathrm{t}, J=7.3 \mathrm{~Hz}, 1 \mathrm{H}), 6.56-$ $6.48(\mathrm{~m}, 2 \mathrm{H}), 5.30(\mathrm{~s}, 1 \mathrm{H}), 5.01(\mathrm{~d}, J=7.9 \mathrm{~Hz}, 1 \mathrm{H}), 4.32(\mathrm{p}, J=7.2 \mathrm{~Hz}, 1 \mathrm{H}), 4.06$ (dd, $J=$ $8.3,5.7 \mathrm{~Hz}, 1 \mathrm{H}), 3.36(\mathrm{dd}, J=9.3,8.3 \mathrm{~Hz}, 1 \mathrm{H}), 3.00(\mathrm{td}, J=8.6,7.5,2.3 \mathrm{~Hz}, 1 \mathrm{H}), 2.00-$ $1.78(\mathrm{~m}, 2 \mathrm{H}), 1.67(\mathrm{~s}, 3 \mathrm{H}), 1.50(\mathrm{~s}, 3 \mathrm{H}) ;{ }^{13} \mathrm{C} \mathrm{NMR}\left(151 \mathrm{MHz}, \mathrm{cdcl}_{3}\right) \delta 171.3,147.4,141.3$, 135.7, 132.7, 129.1, 128.5, 127.7, 126.2, 118.3, 114.0, 92.9, 70.1, 59.9, 55.3, 55.0, 28.0, 23.5, 27.1 (carbon not directly observed); ${ }^{19} \mathrm{~F}$ NMR (376 MHz, Chloroform- $d$ ) $\delta-56.52$. HRMS (DART ionization, orbitrap mass analyzer) calcd for $\mathrm{C}_{12} \mathrm{H}_{12} \mathrm{FNO}_{2}[\mathrm{M}+\mathrm{H}]$ 405.17899, found 405.17844. 
(6R,7aS)-3,3-dimethyl-6-((S)-(phenylamino)(2-(trifluoromethyl)phenyl)methyl)tetrahydro-3H, $5 H$-pyrrolo[1,2-c]oxazol-5-one (7)

Lithium diisopropylamide $(275.9 \mathrm{mg}, 2.6 \mathrm{mmol})$ was dissolved in THF $(2.69 \mathrm{~mL})$ and cooled to $-78^{\circ} \mathrm{C}$. To this mixture was added $1 \mathbf{a}(100 \mathrm{mg}, 0.65 \mathrm{mmol})$ dissolved in THF $(2.69 \mathrm{~mL})$ and was allowed to stir for 10 minutes. Imine $2(209 \mathrm{mg}, 0.84 \mathrm{mmol})$ dissolved in THF $(1.08 \mathrm{~mL})$ was added. After $2 \mathrm{~h}$, the reaction was quenched with $\mathrm{pH} 7$ phosphate buffer $(6 \mathrm{~mL})$ and allowed to warm. The mixture was extracted $3 \times 15 \mathrm{~mL}$ with $\mathrm{Et}_{2} \mathrm{O}$, dried over $\mathrm{Na}_{2} \mathrm{SO}_{4}$, and rotary evaporated. The resulting yellow oil was purified using flash chromatography with $60 \%$ diethyl $\mathrm{Et}_{2} \mathrm{O} /$ pentane and rotary evaporated to yield $127.4 \mathrm{mg}$ (49\%) of yellow oil. $\left(R_{\mathrm{f}}=0.70\right.$ in $40 \%$ EtOAc/hexanes) ${ }^{1} \mathrm{H} \mathrm{NMR}\left(599 \mathrm{MHz}, \mathrm{CDCl}_{3}\right) \delta 8.01$ $(\mathrm{d}, J=8.0 \mathrm{~Hz}, 1 \mathrm{H}), 7.63(\mathrm{dd}, J=7.9,1.3 \mathrm{~Hz}, 1 \mathrm{H}), 7.49(\mathrm{t}, J=7.6 \mathrm{~Hz}, 1 \mathrm{H}), 7.30(\mathrm{t}, J=7.7$ $\mathrm{Hz}, 1 \mathrm{H}), 7.11-7.07(\mathrm{~m}, 1 \mathrm{H}), 6.67(\mathrm{tt}, J=7.3,1.1 \mathrm{~Hz}, 1 \mathrm{H}), 6.62-6.59(\mathrm{~m}, 1 \mathrm{H}), 5.47(\mathrm{~d}, J=$ $9.4 \mathrm{~Hz}, 1 \mathrm{H}), 4.95(\mathrm{~d}, J=8.9 \mathrm{~Hz}, 1 \mathrm{H}), 4.17-4.04(\mathrm{~m}, 1 \mathrm{H}), 3.54-3.46(\mathrm{~m}, 1 \mathrm{H}), 3.31$ (ddd, $J$ $=12.8,7.4,2.2 \mathrm{~Hz}, 1 \mathrm{H}), 2.38(\mathrm{ddd}, J=12.4,7.4,5.4 \mathrm{~Hz}, 1 \mathrm{H}), 1.99(\mathrm{td}, J=12.3,8.9 \mathrm{~Hz}$, $1 \mathrm{H}), 1.75(\mathrm{~s}, 1 \mathrm{H}), 1.45(\mathrm{~s}, 1 \mathrm{H}) .{ }^{13} \mathrm{C}$ NMR $\left(151 \mathrm{MHz}, \mathrm{cdcl}_{3}\right) \delta 170.6,146.9,141.2,132.2$, 129.2, 128.8, 127.2, 125.9, 118.4, 114.2, 91.6, 69.7, 58.6, 54.0, 53.4, 31.1, 23.8, 26.5 (carbon not directly observed); ${ }^{19} \mathrm{~F}$ NMR $(376 \mathrm{MHz}$, Chloroform- $d$ ) $\delta-58.13$; HRMS (DART ionization, orbitrap mass analyzer) calcd for $\mathrm{C}_{12} \mathrm{H}_{12} \mathrm{FNO}_{2}[\mathrm{M}+\mathrm{H}] 405.17899$, found 405.17844 .

\section{(S,E)-3,3-dimethyl-6-(2-(trifluoromethyl)benzylidene)tetrahydro-3H,5H-pyrrolo[1,2- c]oxazol-5-one (15)}

Lithium diisopropylamide $(74.3 \mathrm{mg}, 0.70 \mathrm{mmol})$ was dissolved in toluene $(2.16 \mathrm{~mL})$ and THF $(0.067 \mathrm{~mL})$ and cooled to $-55^{\circ} \mathrm{C}$. To this mixture was added $1 \mathbf{a}(100 \mathrm{mg}, 0.64 \mathrm{mmol})$ dissolved in toluene $(1.56 \mathrm{~mL})$ and was allowed to stir for 10 minutes. Imine $2(210 \mathrm{mg}$, $0.83 \mathrm{mmol})$ dissolved in toluene $(2.68 \mathrm{~mL})$ was added. After $6 \mathrm{~h}$, the reaction was quenched with $\mathrm{pH} 7$ phosphate buffer $(6 \mathrm{~mL})$ and allowed to warm. The mixture was extracted $3 \times 20$ $\mathrm{mL}$ with $\mathrm{Et}_{2} \mathrm{O}$, dried over $\mathrm{Na}_{2} \mathrm{SO}_{4}$, and rotary evaporated. The resulting yellow oil was purified using flash chromatography using a gradient of diethyl ether/pentane mixtures and rotary evaporated to yield $88 \mathrm{mg}(44 \%)$ of white solid. $\left(R_{\mathrm{f}}=0.45\right.$ in diethyl ether $) ; \mathrm{mp}=$ 106.9-112.4; ${ }^{1} \mathrm{H}$ NMR ${ }^{1} \mathrm{H}$ NMR $\left(599 \mathrm{MHz}, \mathrm{CDCl}_{3}\right) \delta 7.70(\mathrm{~d}, J=7.8 \mathrm{~Hz}, 1 \mathrm{H}), 7.55(\mathrm{~s}, 1 \mathrm{H})$, $7.53(\mathrm{t}, J=7.7 \mathrm{~Hz}, 1 \mathrm{H}), 7.42(\mathrm{~d}, J=7.3 \mathrm{~Hz}, 2 \mathrm{H}), 7.40(\mathrm{~d}, J=7.7 \mathrm{~Hz}, 1 \mathrm{H}), 4.23-4.13(\mathrm{~m}$, $2 \mathrm{H}$ ), 3.47 (dd, $J=9.4,7.8 \mathrm{~Hz}, 1 \mathrm{H}$ ), 2.99 (ddd, $J=16.9,6.7,2.1 \mathrm{~Hz}, 1 \mathrm{H}$ ), 2.68 (ddd, $J=17.0$, 5.6, 3.6 Hz, 1H), $1.74(\mathrm{~s}, 3 \mathrm{H}), 1.54(\mathrm{~s}, 3 \mathrm{H}) ;{ }^{13} \mathrm{C}$ NMR $(126 \mathrm{MHz}$, Chloroform- $d) \delta 171.6$, $142.8,137.8,136.7,132.0,128.7\left(\mathrm{q},{ }^{2} J_{\mathrm{C}-\mathrm{F}}=28.9 \mathrm{~Hz}\right), 128.2,127.6\left(\mathrm{q},{ }^{3} J_{\mathrm{C}-\mathrm{F}}=9.9 \mathrm{~Hz}\right)$ $126.8,126.2\left(\mathrm{q},{ }^{3} J_{\mathrm{C}-\mathrm{F}}=5.7 \mathrm{~Hz}\right), 124.2\left(\mathrm{q},{ }^{1} J_{\mathrm{C}-\mathrm{F}}=274 \mathrm{~Hz}\right), 119.4,92.6,67.1,64.6,29.2$, 28.8, 23.0; ${ }^{19} \mathrm{~F}$ NMR (376 MHz, $\mathrm{CDCl}_{3}$ ) $\delta-59.92$; HRMS (DART ionization, orbitrap mass analyzer) calcd for $\mathrm{C}_{12} \mathrm{H}_{12} \mathrm{FNO}_{2}[\mathrm{M}+\mathrm{H}] 312.12114$, found 312.12059 .

\section{(S,Z)-3,3-dimethyl-6-(2-(trifluoromethyl)benzylidene)tetrahydro-3H,5H-pyrrolo[1,2- c]oxazol-5-one (16)}

Lithium diisopropylamide $(74.3 \mathrm{mg}, 0.70 \mathrm{mmol})$ was dissolved in THF $(2.16 \mathrm{~mL})$ at $-55^{\circ} \mathrm{C}$. To this mixture was added $1 \mathbf{a}(100 \mathrm{mg}, 0.64 \mathrm{mmol})$ dissolved in THF $(1.56 \mathrm{~mL})$ and was allowed to stir for 10 minutes. Imine 2 (210 mg, $0.83 \mathrm{mmol})$ dissolved in THF $(2.68 \mathrm{~mL})$ 
was added. After $2 \mathrm{~h}$, the reaction was allowed to warm to room temp and stirred for an additional $30 \mathrm{~min}$. The reaction was then quenched with $\mathrm{pH} 7$ phosphate buffer $(10 \mathrm{~mL})$, extracted $3 \times 20 \mathrm{~mL}$ with $\mathrm{Et}_{2} \mathrm{O}$, dried over $\mathrm{Na}_{2} \mathrm{SO}_{4}$, and rotary evaporated. The resulting yellow oil was purified using flash chromatography using a gradient of diethyl ether/pentane mixtures and rotary evaporated to yield $60 \mathrm{mg}(30 \%)$ of yellow oil. $\left(R_{\mathrm{f}}=0.71\right.$ in diethyl ether); ${ }^{1} \mathrm{H}$ NMR (599 MHz, Chloroform- $d$ ) $\delta 7.64$ (d, $\left.J=7.8 \mathrm{~Hz}, 1 \mathrm{H}\right), 7.47$ (t, $J=7.5 \mathrm{~Hz}$, $1 \mathrm{H}), 7.39$ (d, $J=7.7 \mathrm{~Hz}, 1 \mathrm{H}), 7.33$ (t, $J=7.7 \mathrm{~Hz}, 1 \mathrm{H}), 6.34$ (s, $1 \mathrm{H}), 4.45$ (ddd, $J=10.0,5.9$, $2.1 \mathrm{~Hz}, 1 \mathrm{H}), 4.03$ (dd, $J=8.1,6.2 \mathrm{~Hz}, 1 \mathrm{H}), 3.73(\mathrm{~s}, 2 \mathrm{H}), 3.20(\mathrm{dd}, J=9.8,8.1 \mathrm{~Hz}, 2 \mathrm{H}), 1.67$ (s, 3H), 1.54 (s, 3H); ${ }^{13} \mathrm{C}$ NMR (126 MHz, Chloroform- $d$ ) $\delta 165.3,138.8,131.6,129.26$ $\left(\mathrm{q},{ }^{3} J_{\mathrm{C}-\mathrm{F}}=10.0 \mathrm{~Hz}\right), 129.20,129.0\left(\mathrm{q},{ }^{2} J_{\mathrm{C}-\mathrm{F}}=30.3 \mathrm{~Hz}\right), 128.2,126.8,126.2\left(\mathrm{q},{ }^{3} J_{\mathrm{C}-\mathrm{F}}=5.5\right.$ $\mathrm{Hz}), 123.9\left(\mathrm{q},{ }^{1} J_{\mathrm{C}-\mathrm{F}}=274 \mathrm{~Hz}\right), 92.2,70.0,58.2,28.9,27.1,23.6 ;{ }^{19} \mathrm{~F}$ NMR $(376 \mathrm{MHz}$, Chloroform- $d$ ) $\delta-59.74$; HRMS (DART ionization, orbitrap mass analyzer) calcd for $\mathrm{C}_{12} \mathrm{H}_{12} \mathrm{FNO}_{2}[\mathrm{M}+\mathrm{H}] 312.12114$, found 312.12059 .

\section{Supplementary Material}

Refer to Web version on PubMed Central for supplementary material.

\section{Acknowledgments}

We thank the National Institutes of Health (GM077167) for support.

\section{References and Footnotes}

1. Wright SW, Choi C, Chung S, Boscoe BP, Drozda SE, Mousseau JJ, Trzupek JD. J. Am. Chem. Soc. 2015; 17:5204.Anderson, DR.; Bunnage, ME.; Curran, KJ.; Dehnhardt, CM.; Gavrin, LK.; Goldberg, JA.; Han, S.; Hepworth, D.; Huang, H-C.; Lee, A.; Lee, KL.; Lovering, FE.; Lowe, MD.; Mathias, JP.; Papaioannou, N.; Patny, A.; Pierce, BS.; Saiah, E.; Strohbach, JW.; Trzupek, JD.; Vargas, R.; Wang, X.; Wright, SW.; Zapf, CW. Bicyclic-Fused Heteroaryl or Aryl Compounds as IRAK4 Inhibitors and their Preparation. WO 2015150995. 2015.

2. Najera C, Yus M. Tetrahedron: Asymmetry. 1999; 10:2245. For a comprehensive bibliography, see ref 3 .

3. Houghton MJ, Biok NA, Huck CJ, Algera RF, Keresztes I, Wright SW, Collum DB. J. Org. Chem. 2016; 81:4149. [PubMed: 27035057]

4 (a). Zhang R, Brownewell F, Madalengoitia JS. Tetrahedron Lett. 1999; 40:2707.(b) Cowley AR, Hill TJ, Kocis P, Moloney MG, Stevenson RD, Thompson AL. Org. Biomol. Chem. 2011; 9:7042. [PubMed: 21858317] (c) Makino K, Shintani K, Yamatake T, Hara O, Hatano K, Hamada Y. Tetrahedron. 2002; 58:9737.(d) Okamoto N, Hara O, Makino K, Hamada Y. Tetrahedron: Asymmetry. 2001; 12:1353.(e) Langlois N, Rakotondradany F. Tetrahedron. 2000; 56:2437.(f) Bailey JH, Byfield ATJ, Davis PJ, Foster AC, Leech M, Moloney MG, Muller M, Prout CK. J. Chem. Soc., Perkin Trans. 2000; 1:1977.

5 (a). Green, JR. Science of Synthesis. Vol. Vol. 8a. Georg Thieme Verlag; New York: 2005. p. 427-486.(b) Schetter B, Mahrwald R. Angew. Chem., Int. Ed. 2006; 45:7506.(c) Arya P, Qin H. Tetrahedron. 2000; 56:917.(d) Caine, D. Comprehensive Organic Synthesis. Trost, BM.; Fleming, I., editors. Vol. Vol. 1. Pergamon; New York: 1989. p. 1Martin SF. Ibid. Vol. 1:475.(e) Plaquevent, J-C.; Cahard, D.; Guillen, F.; Green, JR. Science of Synthesis. Vol. Vol. 26. Georg Thieme Verlag; New York: 2005. p. 463-511.(f) Katritzky, Alan R.; Taylor, Richard J. K., editors. Comprehensive Organic Functional Group Transformations II. Elsevier; Oxford, U.K.: 1995. p. 834-835.(g) Cativiela C, Diaz-de-Villegas MD. Tetrahedron: Asymmetry. 2007; 18:569.(h) Dugger RW, Ragan JA, Ripin DHB. Org. Process Res. Dev. 2005; 9:253.(i) Farina V, Reeves JT, Senanayake CH, Song JJ. Chem. Rev. 2006; 106:2734. [PubMed: 16836298] (j) Wu G, Huang 
M. Chem. Rev. 2006; 106:2596. [PubMed: 16836294] (k) Harrison-Marchand A, Mongin F. Chem. Rev. 2013; 113:7470. [PubMed: 23952819]

6 (a). Bowler AN, Doyle PM, Hitchcock PB, Young DW. Tetrahedron Lett. 1991; 32:2679.(b) Juaristi, E., editor. Enantioselective Synthesis of b-Amino Acids. Wiley-VCH; New York: 1997. (c) Sewald N. Angew. Chem., Int. Ed. 2003; 42:5794.(d) Ma J-A. Angew. Chem., Int. Ed. 2003; 42:4290.(e) Liu M, Sibi MP. Tetrahedron. 2002; 58:7991.(f) Abele S, Seebach D. Eur. J. Org. Chem. 2000:1.(g) Cardillo G, Tomasini C. Chem. Soc. Rev. 1996:117.(h) Juaristi E, Quintana D, Escalante J. Aldrichimica Acta. 1994; 27:3.(h) Michel K, Froehlich R, Wuerthwein E-U. Eur. J. Org. Chem. 2009:5653.(i) Hata S, Iwasawa T, Iguchi M, Yamada K, Tomioka K. Synthesis. 2004:1471.(j) Braun M, Sacha H, Galle D, Baskaran S. Pure Appl. Chem. 1996; 68:561.(1) Iwasaki G, Shibasaki M. Tetrahedron Lett. 1987; 28:3257.(m) Denmark, SE.; Nicaise, OJ-C. Chapter 26.2. In: Jacobsen, EN.; Pfaltz, A.; Yamamoto, Y., editors. Comprehensive Asymmetric Catalysis. Springer-Verlag; Heidelberg: 1999. (n) Kobayashi S, Ishitani H. Chem. Rev. 1999; 99:1069. [PubMed: 11749440] (o) Enders D, Reinhold U. Tetrahedron: Asymmetry. 1997; 8:1895.(p) Volkmann, RA. Chapter 1.12. In: Trost, BM.; Fleming, I., editors. Comprehensive Organic Synthesis. Pergamon; Oxford: 1991. (q) Bloch R. Chem. Rev. 1998; 98:1407. [PubMed: 11848938] (r) Dugger RW, Ragan JA, Ripin DHB. Org. Process Res. Dev. 2005; 9:253.(s) Farina V, Reeves JT, Senanayake CH, Song JJ. Chem. Rev. 2006; 106:2734. [PubMed: 16836298] (t) Wu G, Huang M. Chem. Rev. 2006; 106:2596. [PubMed: 16836294] (u) Iza A, Vicario JL, Carrillo L, Badía D. Synthesis. 2006; 23:4065.(v) Vicario JL, Badia D, Carrillo L. J. Org. Chem. 2001; 66:9030. [PubMed: 11749640] (w) Sikriwal D, Kant R, Maulik PR, Dikshit DK. Tetrahedron. 2010; 66:6167.(x) Qian P, Xie C, Wu L, Mei H, Soloshonok VA, Han J, Pan Y. Org. Biomol. Chem. 2014; 12:7909. [PubMed: 25220306]

7. De Vries TS, Bruneau AM, Liou LR, Subramanian H, Collum DB. J. Am. Chem. Soc. 2013; $135: 4214$.

8. For examples in which imines are used to probe organolithium mechanism, see ref 7.

9 (a). Anwar M, Bailey JH, Dickinson LC, Edwards HJ, Goswami R, Moloney MG. Org. Biomol. Chem. 2003; 1:2364. [PubMed: 12945710] For additional azaaldol additions of pyroglutaminolderived enolates see: Bowler AN, Doyle PM, Hitchcock PB, Young DW. Tetrahedron Lett. 1991; 32:2679. Avent AG, Bowler AN, Hitchcock PB, Young DW. Tetrahedron Lett. 1992; 33:1509. Anwar M, Bailey JH, Dickinson LC, Edwards HJ, Goswami R, Moloney MG. Org. Biomol. Chem. 2003; 1:2364. [PubMed: 12945710]

10. Collum DB. Acc. Chem. Res. 1993; 26:227.

11. Ma Y, Hoepker AC, Gupta L, Faggin MF, Collum DB. J. Am. Chem. Soc. 2010; 132:15610. [PubMed: 20961095]

12. Frisch, MJ., et al. GaussianVersion 3.09. revision A.1. Gaussian, Inc.; Wallingford, CT: 2009.

13 (a). For leading references to theoretical studies of O-lithiated species, see: Khartabi HK, Gros PC, Fort Y, Ruiz-Lopez MF. J. Org. Chem. 2006; 73:9393. Streitwieser A. J. Mol. Model. 2006; 12:673. [PubMed: 16341718] Pratt LM, Streitwieser A. J. Org. Chem. 2003; 68:2830. [PubMed: 12662059] Pratt LM, Nguyen SC, Thanh BT. J. Org. Chem. 2008; 73:6086. [PubMed: 18646860]

14 (a). Gakh YG, Gakh AA, Gronenborn AM. Magn. Reson. Chem. 2000; 38:551.(b) McGill CA, Nordon A, Littlejohn D. J. Process Anal. Chem. 2001; 6:36.(c) Espinet P, Albeniz AC, Casares JA, Martinez-Ilarduya JM. Coord. Chem. Rev. 2008; 252:2180.

15. Yagi K, Shinokubo H, Oshima K. Org. Lett. 2004; 6:4339. [PubMed: 15524478]

16 (a). Seebach D. Angew. Chem., Int. Ed. Engl. 1988; 27:1624.(d) Braun M. Helv. Chim. Acta. 2015; 98:1.Seebach, D. Proceedings of the Robert A. Welch Foundation Conferences on Chemistry and Biochemistry; New York: Wiley; 1984. p. 93

17. Collum DB, McNeil AJ, Ramírez A. Angew. Chem., Int. Ed. 2007; 46:3002.

18. Deaggregation tends to occur at low temperatures owing to the dominant enthalpy of solvation.

19 (a). Lucht BL, Collum DB. J. Am. Chem. Soc. 1995; 117:9863.(b) Scheschkewitz D. Angew. Chem., Int. Ed. Engl. 2004; 43:2965. [PubMed: 15170317] (c) Niecke E, Nieger M, Schmidt O, Gudat D, Schoeller WW. J. Am. Chem. Soc. 1999; 121:519.(d) Becker G, Eschbach B, Mundt O, Reti M, Niecke E, Issberner K, Nieger M, Thelen V, Noth H, Waldhor R, Schmidt M. Z. Anorg. Allg. Chem. 1998; 624:469.(e) Becker G, Schwarz W, Seidler N, Westerhausen M. Z. Anorg. Allg. Chem. 1992; 612:72.(f) Wang H, Wang H, Li H-W, Xie Z. Organometallics. 2004; 23:875. 
(g) Xu X, Zhang Z, Yao Y, Zhang Y, Shen Q. Inorg. Chem. 2007; 46:9379. [PubMed: 17880064] (h) Thiele K, Goris H, Imhof W, Seide W. Z. Anorg. Allg. Chem. 2002; 628:107.(i) Ramirez A, Lobkovsky E, Collum DB. J. Am. Chem. Soc. 2003; 125:15376. [PubMed: 14664582] (j)

Buchalski P, Grabowska I, Kaminska E, Suwinska K. Organometallics. 2008; 27:2346.

20 . We define the idealized rate law as that obtained by rounding the observed reaction orders to the nearest rational order.

21. The rate law provides the stoichiometry of the transition structure relative to that of the reactants: Edwards JO, Greene EF, Ross J. J. Chem. Educ. 1968; 45:381.

22. Through-space Li-F interactions have been detected. For example, see: Stalke D, Klingebiel U, Sheldrick GM. Chem. Ber. 1988; 121:1457. Armstrong DR, Khandelwal AH, Kerr LC, Peasey S, Raithby PR, Shields GP, Snaith R, Wright DS. Chem. Commun. 1998:1011. Plenio H, Diodone R. J. Am. Chem. Soc. 1996; 118:356. Henderson KW, Dorigo AE, Liu Q-Y, Williard PG. J. Am. Chem. Soc. 1997; 119:11855.

23. As the minimization proceeded, a desolvation was evidenced by a significant elongation of the $\mathrm{Li}-$ $\mathrm{O}$ bond, but then returned to a normal bond length on the adjoining lithium.

24 (a). Thompson A, Corley EG, Huntington MF, Grabowski EJJ, Remenar JF, Collum DB. J. Am. Chem. Soc. 1998; 120:2028. and references cited therein. For other additional examples, see: Arvidsson PI, Davidsson Ö. Angew. Chem., Int. Ed. Engl. 2000; 39:1467. [PubMed: 10777644] Arvidsson PI, Hilmersson G, Davidsson Ö. Chem. Eur. J. 1999; 5:2348. Fressigne C, Corruble A, Valnot JY, Maddaluno J, Giessner-Prettre C. J. Organomet. Chem. 1997; 549:81. Sato D, Kawasaki H, Koga K. Chem. Pharm. Bull. 1997; 45:1399. Nudelman NS, Schulz HG. J. Chem. Soc., Perkin Trans. 2. 1999:2761. Tallmadge EH, Collum DB. J. Am. Chem. Soc. 2015; 137:13087. [PubMed: 26437278] Oulyadi H, Fressigne C, Yuan Y, Maddaluno J, HarrisonMarchand A. Organometallics. 2012; 31:4801-4809. Ma Y, Stivala CE, Wright AM, Hayton T, Liang J, Keresztes I, Lobkovsky E, Collum DB, Zakarian Z. J. Am. Chem. Soc. 2013; 135:16853. [PubMed: 23654300]

25 (a). Spectroscopic studies of lithium salts of dianions: Li D, Keresztes I, Hopson R, Williard PG. Acc. Chem. Res. 2009; 42:270. [PubMed: 19105594] Gareyev R, Ciula JC, Streitwieser A. J. Org. Chem. 1996; 61:4589. [PubMed: 11667384] Gruver JM, West SP, Collum DB, Sarpong R. J. Am. Chem. Soc. 2010; 132:13212. [PubMed: 20822143] Brand H, Capriotti JA, Arnold J. Inorg. Chem. 1994; 33:4334. Günther H. J. Braz. Chem. Soc. 1999; 10:241. Li D, Keresztes I, Hopson R, Williard PG. Acc. Chem. Res. 2009; 42:270. [PubMed: 19105594] Jacobson MA, Keresztes I, Williard PG. J. Am. Chem. Soc. 2005; 127:4965. [PubMed: 15796563] Cohen Y, Roelofs NH, Reinhardt G, Scott LT, Rabinovitz M. J. Org. Chem. 1987; 52:4207. Matsuo T, Mizue T, Sekiguchi A. Chem. Lett. 2000:896.

26 (a). For representative examples of X-ray crystal structures of dianions, see: Selinka C, Stalke D. Z. Naturforsch., B: Chem. Sci. 2003; 58:291. Konrad TM, Grunwald KR, Belaj F, Mosch-Zanetti NC. Inorg. Chem. 2009; 48:369. [PubMed: 19061386] Williard PG, Jacobson MA. Org. Lett. 2000; 2:2753. [PubMed: 10964357] Brooks JJ, Rhine W, Stucky GD. J. Am. Chem. Soc. 1972; 94:7346. Sekiguchi A, Ebata K, Kabuto C, Sakurai H. J. Am. Chem. Soc. 1991; 113:7081. Sekiguchi A, Ichinohe M, Kabuto C, Sakurai H. Organometallics. 1995; 14:1092. Wilhelm D, Dietrich H, Clark T, Mahdi W, Kos AJ, Schleyer P. v. R. J. Am. Chem. Soc. 1984; 106:7279. Henderson KW, Dorigo AE, MacEwan GJ, Williard PG. Tetrahedron. 2011; 67:10291. Brask JK, Chivers T, Yap GPA. Inorg. Chem. 1999; 38:5588. [PubMed: 11671287] Wilhelm D, Clark T, Schleyer P. v. R. Dietrich H, Mahdi W. J. Organomet. Chem. 1985; 280:C6. Lappert MF, Raston CL, Skelton BW, White AH. J. Chem. Soc., Chem. Commun. 1982:14.

27. Gruver JM, West SP, Collum DB, Sarpong R. J. Am. Chem. Soc. 2010; 132:13212. [PubMed: 20822143]

28. Kofron WG, Baclawski LM. J. Org. Chem. 1976; 41:1879.

29. Boyd DB, Foster BJ, Hatfield LD, Hornback WJ, Jones ND, Munroe EJ, Swartzendruber JK. Tetrahedron Lett. 1986; 27:3457. 


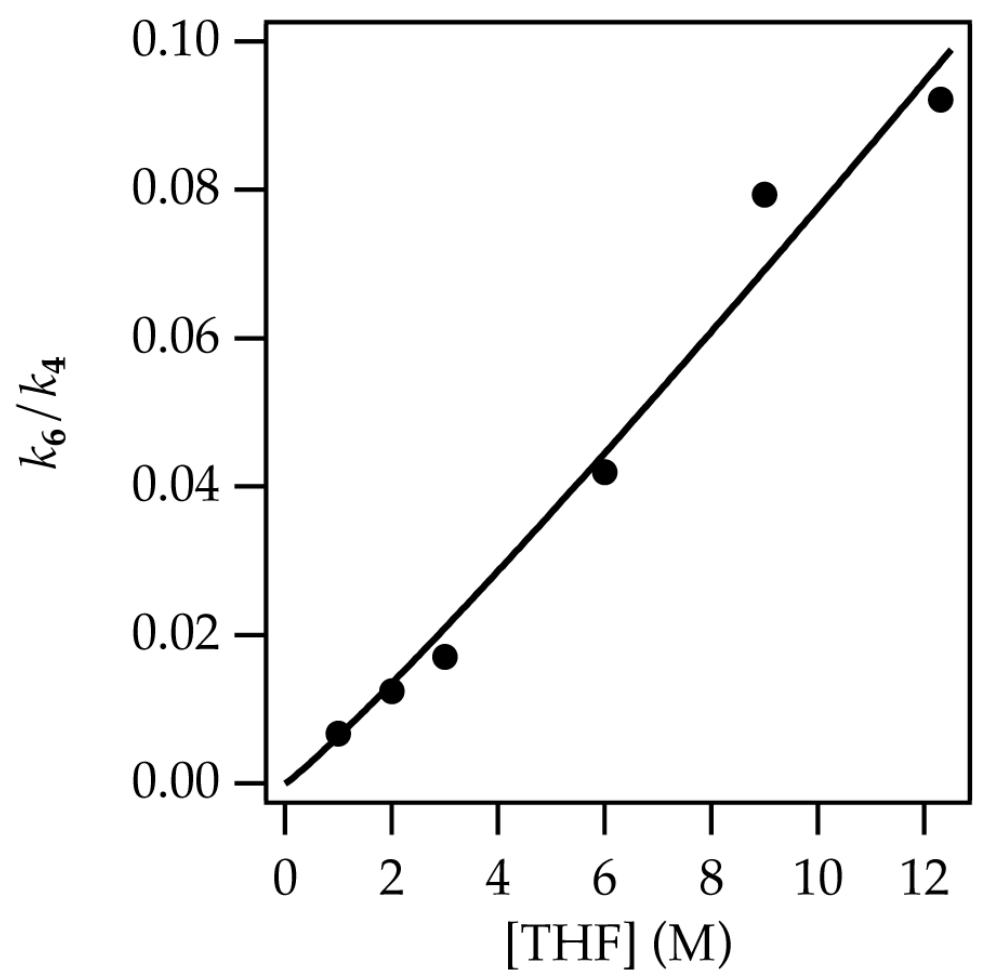

Figure 1.

Plot of $k_{6} / k_{4}$ vs tetrahydrofuran (THF) concentration (M) as determined by carrying out the addition of lithium enolate $3(0.10 \mathrm{M})$ with imine $2(0.13 \mathrm{M})$ at $-78{ }^{\circ} \mathrm{C}$ and monitoring the proportions of $\mathbf{6}$ and $\mathbf{4}$ in quenched aliquots with ${ }^{19} \mathrm{~F}$ NMR spectroscopy. The curve depicts an unweighted least-squares fit to $y=k[\mathrm{THF}]^{n}\left[k=(6.4 \pm 2.0) \times 10^{-3}, n=1.09 \pm 0.13\right]$. 


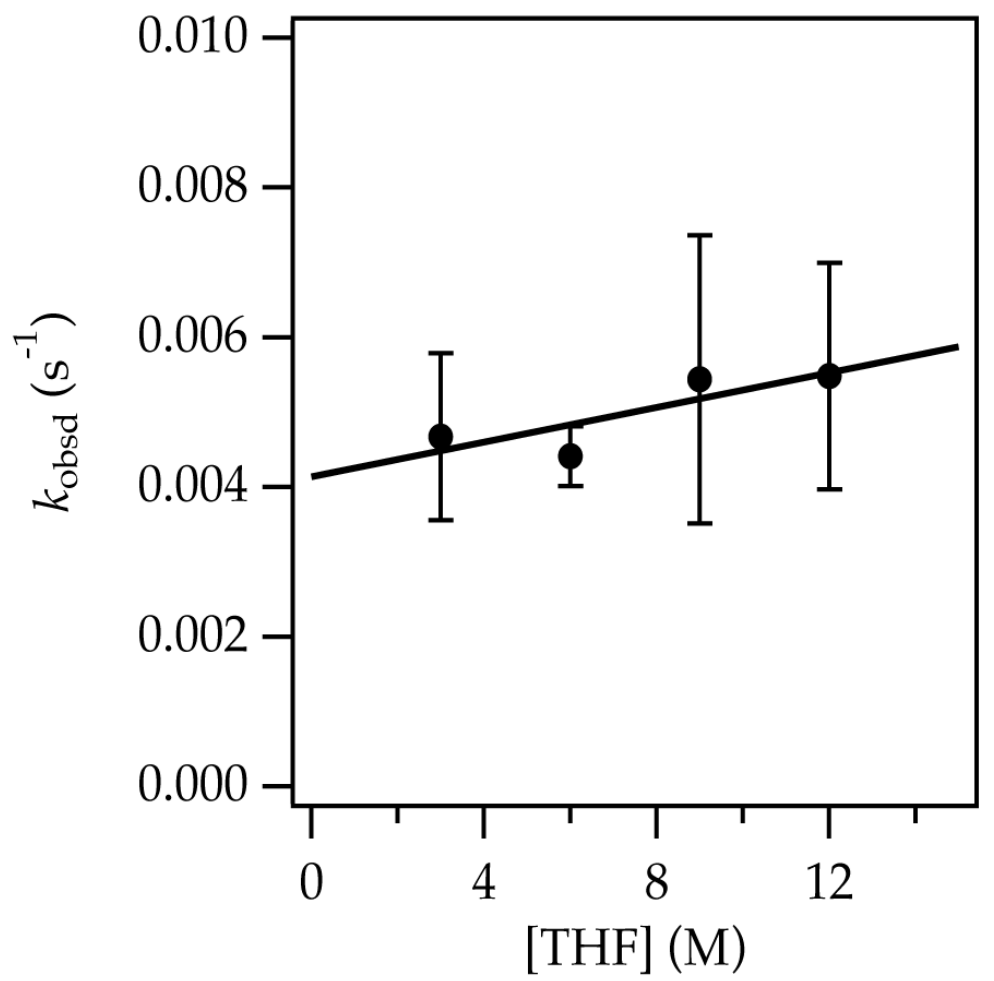

Figure 2.

Plot of $k_{\text {obsd }}$ Vs THF concentration (M) in toluene cosolvent for the addition of lithium enolate $3(0.10 \mathrm{M})$ to imine $2(0.005 \mathrm{M})$ at $-70{ }^{\circ} \mathrm{C}$. The curve depicts an unweighted leastsquares fit to $k_{\text {obsd }}=k+k^{\prime}[\mathrm{THF}]\left[k=(4.1 \pm 0.5) \times 10^{-3}, k^{\prime}=(1.2 \pm 0.6) \times 10^{-4}\right]$. 


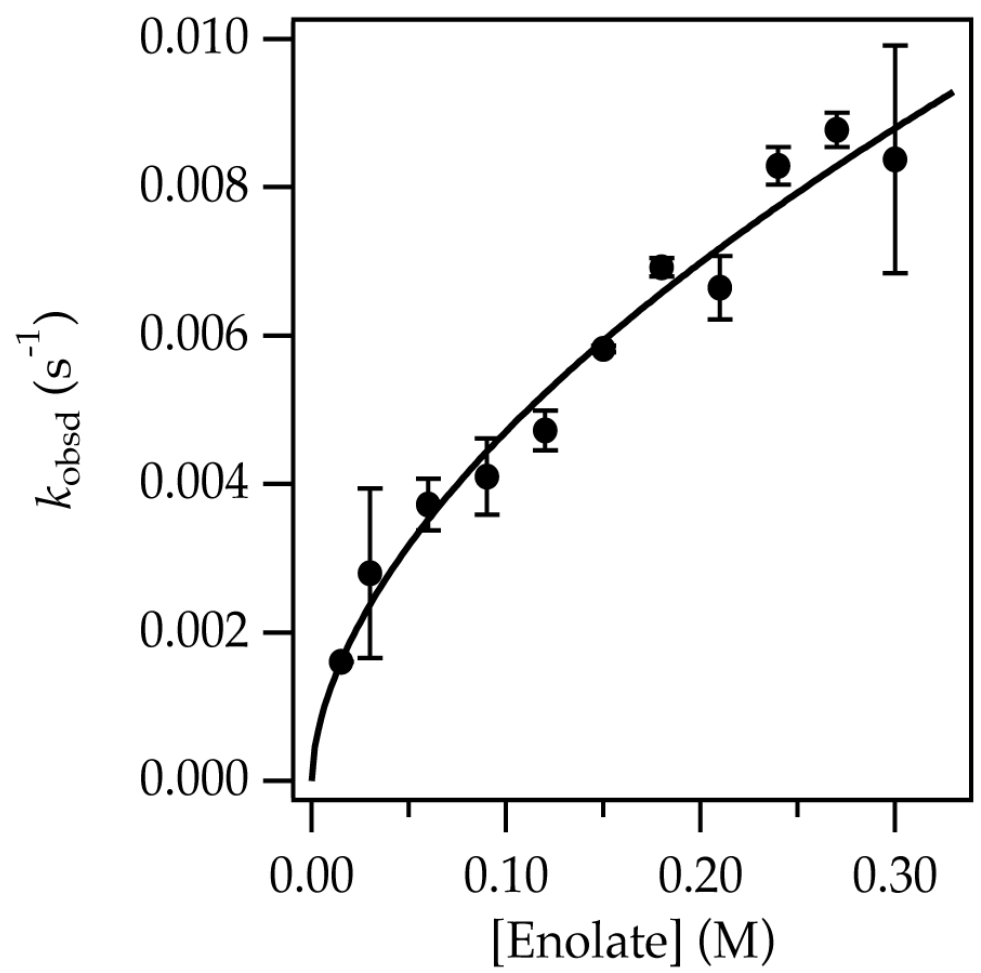

Figure 3.

Plot of $k_{\text {obsd }}$ vs concentration of enolate $\mathbf{3}$ for the addition of lithium enolate $\mathbf{3}$ to imine $\mathbf{2}$ $(0.003 \mathrm{M})$ in $12.3 \mathrm{M} \mathrm{THF}$ at $-70{ }^{\circ} \mathrm{C}$. The curve depicts an unweighted least-squares fit to $y$ $=k[3]^{n}[k=0.017 \pm 0.001, n=0.57 \pm 0.05]$. 


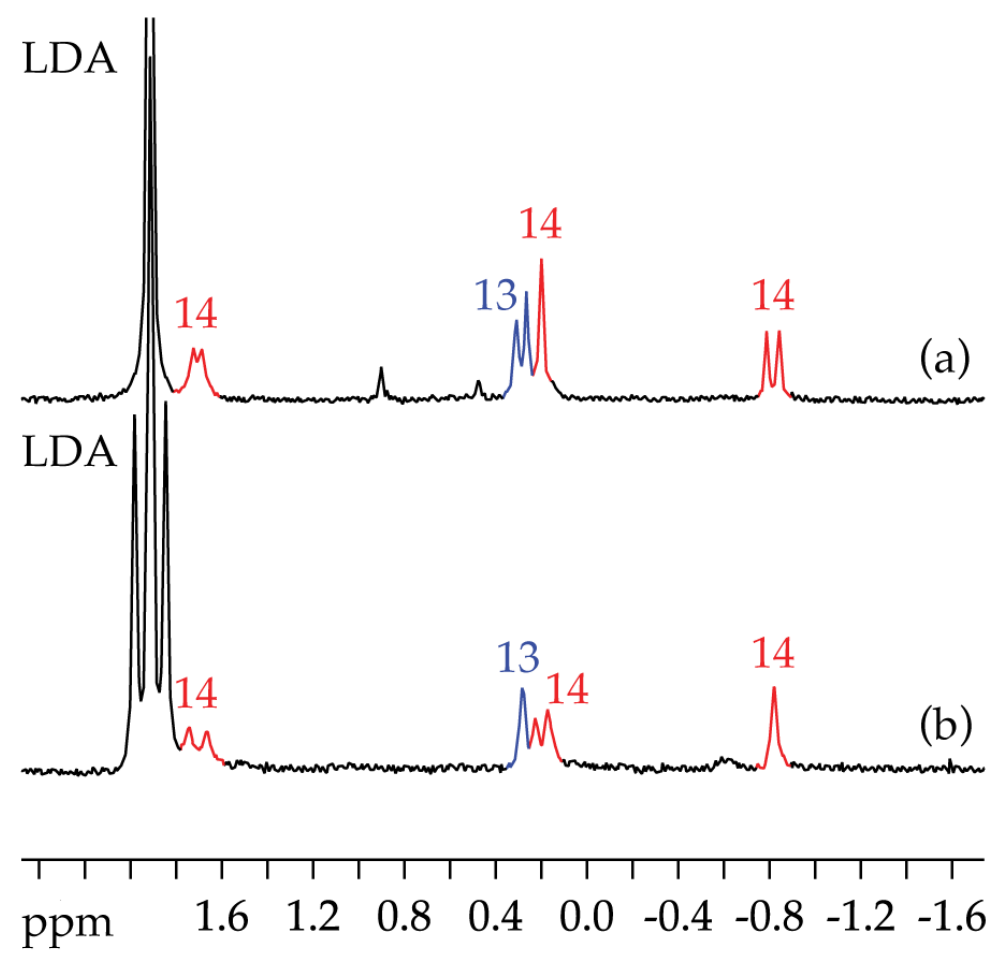

Figure 4.

${ }^{6} \mathrm{Li}$ NMR spectra of $0.10 \mathrm{M}$ enolate 3 with $0.40 \mathrm{M}$ excess lithium diisopropylamide (LDA) showing dianion 13 (blue) and trilithiated dianion-LDA mixed aggregate 14 (red): (a) $\left[{ }^{6} \mathrm{Li},{ }^{15} \mathrm{~N}\right] \mathbf{4}$ and $\left[{ }^{6} \mathrm{Li}\right] \mathrm{LDA}$; (b) $\left[{ }^{6} \mathrm{Li}\right] \mathbf{4}$ and $\left[{ }^{6} \mathrm{Li},{ }^{15} \mathrm{~N}\right] \mathrm{LDA}$. 


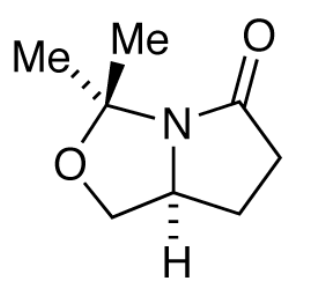

$1 a$<smiles>CCc1cc(Br)ccc1C(F)(F)F</smiles>

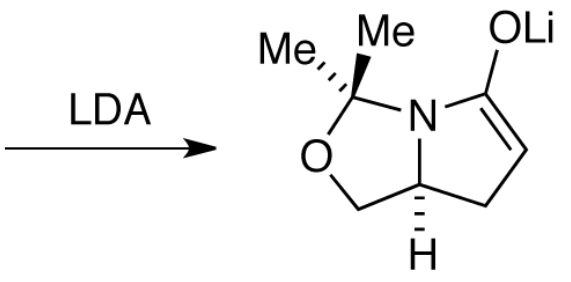

3

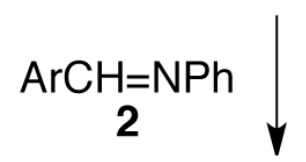<smiles>CC1(C)OC[C@H]2C[C@H]([C@H]([Al])Nc3ccccc3)C(=O)N21</smiles>

4 $>99 \%$ diastereoselective $78 \%$ yield

Scheme 1. 

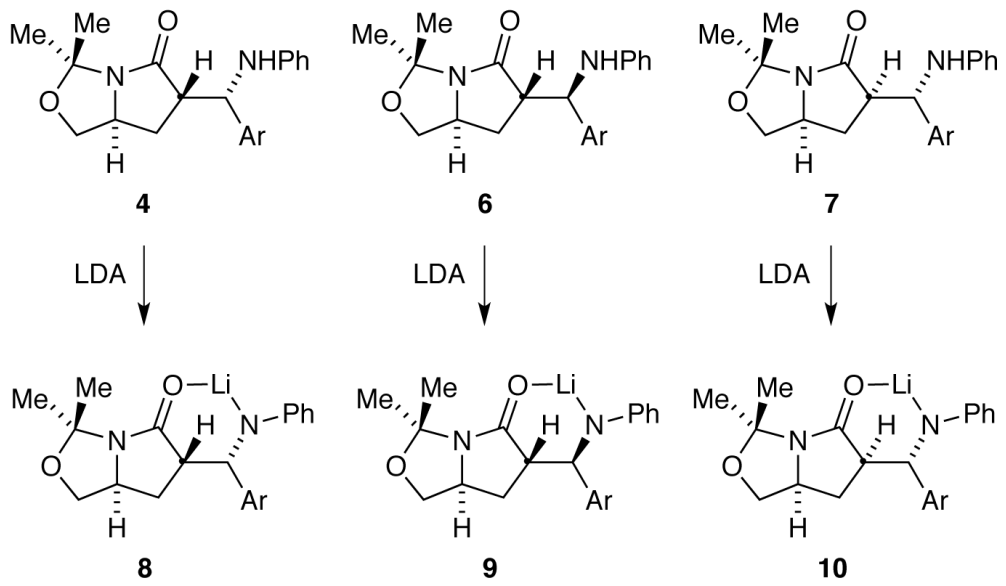

Scheme 2. 

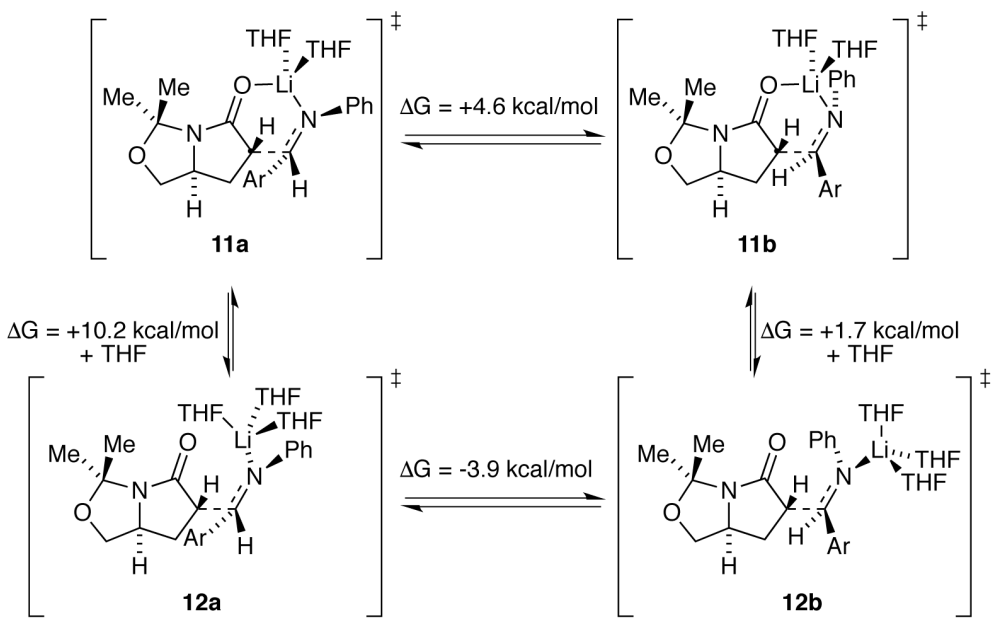

Scheme 3. 


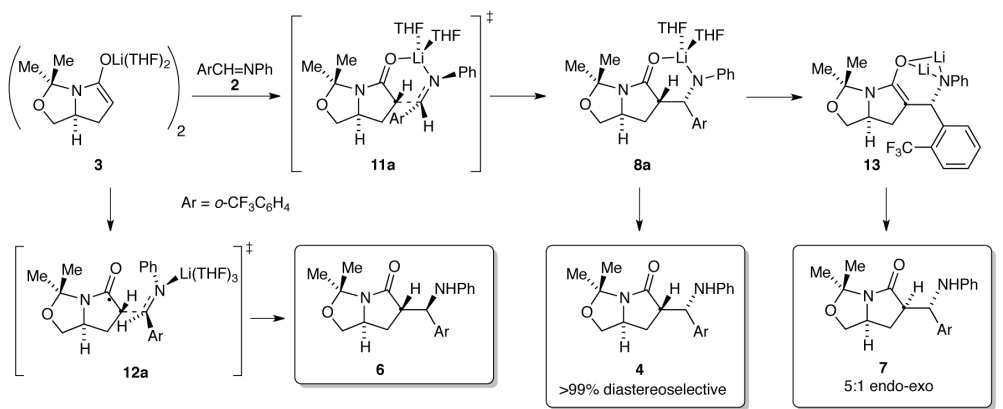

Scheme 4. 

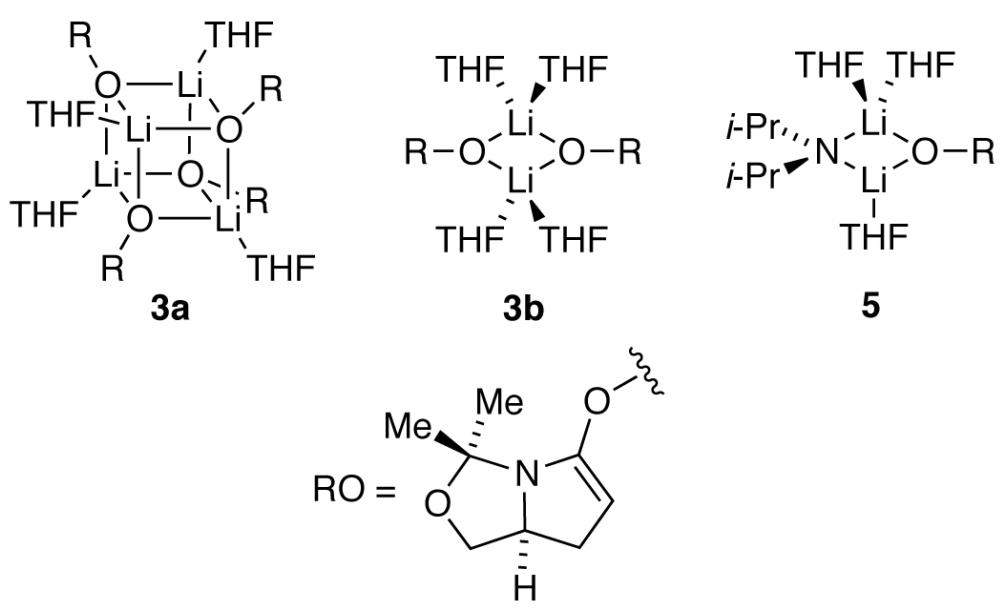

Chart 1. 


\section{Table 1}

Tetrahydrofuran (THF)- and temperature-dependent stereoselectivities (eq 1). ${ }^{a}$

\begin{tabular}{lll}
\hline Temp $\left({ }^{\circ} \mathbf{C}\right)$ & {$[\mathbf{T H F}](\mathbf{M})$} & $\mathbf{4 : 6}$ \\
\hline-78 & 12 & $11: 1$ \\
-78 & 1.0 & $150: 1$ \\
-55 & 12 & $14: 1$ \\
-55 & 1.0 & $>200: 1$ \\
\hline \multicolumn{3}{c}{ Lithium diisopropylamide $=0.10 \mathrm{M} ;$ imine $2=0.13 \mathrm{M}}$.
\end{tabular}

